\title{
"Back to the future": Socio-technical imaginaries in 50 years of school digitalization curriculum reforms
}

\author{
Annika Bergviken Rensfeldt ${ }^{1}$ \\ University of Gothenburg \\ Email: annika.bergviken-rensfeldt@gu.se \\ Catarina Player-Koro \\ University of Gothenburg \\ Email: catarina.player-koro@gu.se
}

\section{Abstract}

This paper examines major Swedish school digitalization curriculum reforms over the past 50 years by analyzing similarities and differences between the late 1960s, mid-1990s, and early 2010s curricular reforms. By drawing on Jasanoff's (2015) socio-technical imaginary concept, we examine how digitalization reforms are constituted discursively and materially in struggles over curricular knowledge content, preferred citizenship roles, and infrastructural investments and especially by relating curricular reforms to governance transformations. One recurrent strategy of reform is what we call the back to the future argument, where curricula address an ideal citizenship of future societies, politically used to support change. We suggest that in the more than 50 years of school digitalization issues, it has been surrounded by strong and shifting struggles over the curriculum content and governance transformations. This pendulum movement (Englund, 2012) has taken place partly through central, state-led or new monopolized technology governance and infrastructures and partly through decentralized forms of governing (e.g., in municipal contexts and via IT-supported networks).

\footnotetext{
${ }^{1}$ Corresponding author

C2020 (Annika Bergviken Rensfeldt/Catarina Player-Koro). This is an Open Access article distributed under the terms of the Creative Commons Attribution 4.0 International License (http://creativecommons.org/licenses/by/4.0/), allowing third parties to copy and redistribute the material in any medium or format and to remix, transform, and build upon the material for any purpose, even commercially, provided the original work is properly cited and states its license.
} 
Keywords: school digitalization; curriculum reform; governance transformation; sociotechnical imaginary; infrastructure; school computers; IT networks; learning platforms

-I felt it was very positive that we could see what was happening around us, as we in Sweden had a slightly different approach to it compared to many other countries. Commonly, others started by introducing computers in more specialized ways and only for some groups, while from the very beginning we said that this should be fully integrated. And we started with upper secondary school of course, and then "data knowledge" [in Swedish, datalära, implemented in the 1980 curriculum Lgr8o, and initiated in the 1970s] was introduced into primary school too.

-After all, we were facing a huge task. The whole body of teachers in both primary and upper secondary school were to receive some continuing education in data knowledge ... and later in the 1980 s it turned out that ... programming, instead of [the new curriculum] data knowledge had taken over. Perhaps, this [data knowledge] project was a little too far ahead in time.

(Nilsson, 2008)

An important goal of the strategy [The national school digitalization strategy by The Ministry of Education, 2017] is that teachers, students, preschool children, principals, and local school management continuously should develop their digital competence. For teachers for example this means having enough knowledge to "choose and use digital tools in education" according to the strategy. This concerns being able to use computers, smart pads, mobiles, digital study materials, programming etc. in teaching to improve students' results.

-One strategy is not enough, rather it is required that both the government and local school management invest in and prioritize the digital school, says the chair of the Teacher Union.

(Teacher Union magazine, 2017-10-20)

\section{Introduction}

In Sweden, it has been well over 50 years since the first political and curricular initiatives on digital technologies in schools similar to the ones that exist today were introduced. Two major curriculum reforms, in 1980 and 2017, are exemplified in the introductory quotations and point to some recurrent features of the reforms. One is the struggle over the knowledge content and what the relevant technologies are considered to be for a future society and citizen, in terms coined by the changes in terminology and actual technologies. Digitalization is the more recent term, but it has been preceded by the terms and technologies of different eras, like computerization and data knowledge in the 1960 s and information and communication technology (ICT) based learning in the 1990s. Another reform feature is what purposes and outcomes school digitalization curricula should have, including when and how it should be introduced. The first quotation above, from an early 
"pioneer" in the field, illustrates some of these tensions and ongoing attempts to introduce digital technologies, as well as the early exchanges and borrowing of ideas on school digitalization between different countries. Arguments for introducing new school digitalization curricula over time can provide examples of how and what the discursive struggles are or have been. The 50 years of digitalization reforms therefore raise questions of what the reemerging ideas of the reforms have been and especially how certain desirable knowledges and technologies for an imagined society and future play an important part in the construction of school digitalization curricula. As our title, "Back to the Future" suggests, such social and performative discourses, together with digital technologies, constitute certain desirable future characteristics, for example, being at the forefront of technological advances as a nation by setting the stage for the future society through education reform and infrastructure investments. Desirable concepts like "modernization," "innovation," and "disruption" have commonly been used for the purpose of motivating digitalization reform and expectations. Therefore, such discursive work is performative and represents a political will to break with the past to shape futures (Popkewitz, 2008), and they function as strategies to motivate curricular reform. We also used the back to the future argument to refer to how such dominant knowledge arguments for the future society, like programming competence and learning to code, also referred to in the introductory quotations, are repeated during the time period in focus here.

School digitalization reforms and investments in technology have always taken place in parallel with developments of digital technologies and scientific knowledge in society, and reforms often involved high expectations of digitalization powers to change, renew, and improve education. Education technologies formed an important part of school curriculum and education reforms early on, in the decades after the second world war, for example, by introducing the needs of digitalization for a science-based future society and competent citizen. Hence, the reconstructions of nation-states' public education and societies included investments in early education technology, and in comparison to many other Nordic countries, Sweden, having avoided the war, is considered to have been early with investing in a strong, equality-oriented public sector (Hallsén \& Nordin, 2020). However, since the 1990s, similarly to other countries, Sweden has conducted a fast dismantling of public sector education to privatize large parts of the education system through market reforms (e.g., Ball \& Youdell, 2007; Englund, 2018; Verger et al., 2017), thereby moving from state to more decentralized governance. Such governance transformations provide democratic challenges. In the second quotation at the start of this paper, the Teacher Union chair references such democratic and economic challenges by addressing the local responsibility for investment and expected competence improvements. Equality-oriented reform ambitions and equal technological accessibility and opportunity throughout the education system could be harder to achieve when school governance is decentralized to local and municipal governments or outsourced to private sector companies. 


\section{Aim, questions and approach}

Swedish school digitalization curriculum reforms make up the case in this article. The aim is to explore the configurations of major digitalization reforms from 1969 to 2019, raising two questions: How are different school digitalization curriculum reforms constituted regarding imaginaries of future societies, knowledge content, and digital technologies? Following this, how are the different reforms converging or diverging over time and in relation to governance transformations?

The approach used here to critically examine curricular digitalization reform draws on Jasanoff's (2015, p. 19) conceptualization of socio-technical imaginaries as part of political reforms and advances in science and technology. Socio-technical imaginaries are formed through socially and publicly performed discourses of desirable future societies, as well as through inscriptions and the materiality of technology. Hence, socio-technical imaginaries include both the discursively and materially intertwined and negotiated formations of digitalization curricula-discourses of futures and future citizens, knowledge content, and the materiality of digital technologies, devices, infrastructures, and investments. This approach suggests that digital "things" are considered co-produced by imagined visions of digitalized futures. Digitalization curricula, covering both discourse and materiality, is one of the most powerful arenas for translations and uptakes of socio-technical imaginaries, and as such, they need to be critically examined.

Other studies have defined school curricula as historically and contingently constituting what are considered the relevant knowledge contents for education in dynamic relation to political processes and reforms (Popkewitz, 2008). In that sense, school curricula are part of political government, nation-state ambitions, and ideals of citizenry competences (Englund, 2012, 2018). Curricular reforms can also be seen as the results of scientific and political struggles, prompting the prioritization of certain educational content and strategies (Bernstein, 2000). Therefore, curricula are not to be considered neutral but rather the result of complex negotiations between different social groups and interests (Lundgren, 1983) along with digital technologies and computers in schools (Selwyn, 2002). Jasanoff's approach allows for analytical sensitivity toward new circumstances and challenges with understanding how socio-technical imaginaries are circulated and adopted. This can include different local, national, or international curricular contexts (e.g., Verger et al., 2017; Wahlström \& Sundberg, 2017). Therefore, even if curricular aspects of education reforms operate across national and global contexts, they will always be adapted and adjusted in relation to the specific needs and traditions of that country, region, or setting. Thus, there is no unidirectional transfer of curricular reform from one site to another; they are best described as multidirectional and contingent.

Examples from education technology research using Jasanoff's concept to explore aspects of school digitalization include Williamson (2017) and Tafdrup (2019). Other critically 
oriented research is seen in UK studies on earlier reforms (McGarr \& Johnston, 2019; Selwyn, 2002) and in Nordic case studies (e.g., Hallsén \& Nordin, 2020; Hanell, 2018; Haugsbakk, 2013; McBride, 2019; Nivala, 2009; Saari \& Säntti, 2018). There is also an emerging related field of study on how education reforms increasingly make use of digital technology for accountability politics, digital governance, and predictions of educational outcomes (e.g., Grek et al., forthcoming; Gulson \& Sellar, 2019; Williamson, 2017).

\section{Materials and analysis}

The materials used for this study are mainly publicly available official documents, including archived interviews, newspaper articles, syllabi, and education policies, including government strategies, evaluations (e.g., Jedeskog, 2005; Riis, 1987), and investments in digital infrastructures. Two quotations introduced the case. The first is from an open archive of testimonial interviews conducted with digitalization pioneers in 2008 for the research project "From Mathematical Machine to Information Technology" (Emanuel, 2009). It includes 10 interviews about school digitalization with "once-powerful education actors" (Selwyn, 2013), allowing for secondary use of personal but also retrospective opinions of what was at stake. Six of these transcribed interviews from 2008 (Boström, Broman \& Bäck, Nilsson, Nilsson \& Loftrup, Nydahl, and Riis) have been repurposed in our analysis. The second quotation is from a database search in the Swedish Media Archive covering the school digitalization reform launched in the autumn of 2017 (see also Williamson et al., 2019).

Because the reform documentation and curricula covering 1969 to 2019 revolve around imagined futures, knowledge, and digital technology, Jasanoff's concept was relevant. An analytical aim was to pay attention to discursive and material content, meaning political and curricular arguments, as well as investments in devices and infrastructures and regarding technology as co-produced by discursive powers. Due to the extensive 50-year period being examined, the overall struggles and main reform elements are primarily represented, making details, local circumstances, and other voices less visible. The long period also made us explore divergences and convergences of the political struggle over time. The time frames were borrowed from Englund's (2012) education reform conceptualization of how educational citizenship equality is addressed and operating via pendulum movements of reform and curricular politics, suggesting a centralistic government in the 1960s, and renewed in 2010 with a clear break of decentralized governance in the 1990s (Englund, 2018). Next, our analysis is presented chronologically as it resulted in three main reforms, one in the late 1960s, the second in the mid-1990s, and most recently in the late 2010s, each displaying certain socio-technical imaginaries at play. 


\section{Programming and school computers in 1960s centralized curriculum reform}

Curricular ideas on computers and digital technologies were officially introduced in the Swedish parliament in the late 1960s, and in 1971, the National Board for Education (NBE) prepared a new school subject, "data knowledge" (datalära, introduced earlier). Textbooks supporting the new school subject, produced by pioneers (Nilsson \& Loftrup, 2008), like Computers on Our Terms in 1976, and A Programmed Future in 1979, say something about the orientation of the subject toward student perspectives and future socio-technical imaginaries. In the 1970 s and 8os, a series of government-funded computer technology initiatives (e.g., the DOS and DIS projects) aimed at developing both hardware and software, and pedagogical methods followed. A government delegation was already sent to the United States in 1966 by the Ministry of Education and Ecclesiastical Affairs to investigate the early generations of education technology, called computer-aided instruction, CAI (Karlsohn, 2009). However, it was not until 1984, 13 years after the commission instantiated, that the first integrated data knowledge curriculum for all school years started. It included 80 hours of teaching in secondary school, with the aim of critically fostering knowledge on computerization in society.

The struggles of the reform were thus a characteristic feature of the digitization curriculum. According to Riis (2008), two main conclusions had been drawn from the earlier projects and recommended to influence the new overall syllabus in the early 1980 , Lgr8o (NBE, 1980a). Riis added that "this is how she remembers it" now, based on her later evaluations. One was that computers should only be introduced in vocational upper secondary school, and another was that the new curriculum should prevent "the mistake from earlier education technology reform," echoing the US and CAI-inspired modularized curricula, so that "drill” and "automatization" would be rejected in favor of students' use and self-control (Riis, 2008).

Sweden, known for its close science and state (party politics), as well as its social and science education ties, epitomized by the state's step-by-step "social engineering," was considered as having advantages compared to other countries in terms of engineering public reform. According to Riis (2008), "Sweden has been about 10 years ahead of almost all other countries in Europe that were involved in the second world war when it comes to school reform," adding that a strong future imaginary and tactic had regulated that government:

Thus, one has a vision of a different and better society ... then one has to place that vision quite far into the future ... so far into the future that it is possible to achieve real decision-making power, on top of or alongside yesterday's old decision. (Riis, 2008) 
Influential state governmental connections during these years also included the domestic industry sector, exemplified in the main vision of the first major initiative, DIS, introducing computers in 1974 to 1980 :

Knowledge is required to increase the individual's influence over computer use. Knowledge of computers and the use of computers is also needed to preserve our country's role as industrial nation (NBE, 198ob, p. 1)

The future imaginary presented is a computerized and industrial society, secured by the knowledgeable individual via schooling and the nation's industrial labor and made governable through social engineering and a strong future imaginary (Jasanoff, 2015). In retrospect, Broman \& Bäck (2008) refers to the shared understanding of digitalization as a "social drama" that influential pioneers used based on the argumentative logic that "a major societal revolution is happening," and "this is what we must do," as "Sweden has to keep our place in the world." This self-reflection mirrors not only the social and argumentative powers of digitalization reform but also how digital technologies are interrelated with the nationally competitive computer-based societal imaginary.

Interestingly, similar to the reform in the 2010s (NEA, 2017), there was also a basic form of programming included in early computer mathematics curriculum. Locally, basic programming was often introduced via self-organized science teachers using invested school computers (Nilsson, 2008, see introductory quotation). A critical evaluation followed the implementation, conducted by Riis (1987), who stated that students had not received the required teaching hours and the results in mathematics had dropped, considered to have been caused by the time-consuming programming in mathematics. According to Nilsson (2008), "software and programming" characterized the period, but "nothing much else happened," as most projects and initiatives were stopped. In 1987, data knowledge was also excluded from the curriculum. Major curricular struggles involving teacher unions also emerged and interrupted the process, and the broad implementation, time, and resources allocated to the new curriculum were debated, despite the fact that state government had prescribed protection of teachers' workloads (Broman \& Bäck, 2008). The alternative curricula also spread as many teachers preferred applied programming (Nilsson, 2008; also introductory quotation). These long curricular struggles and strong trade union resistance protracted establishing the curriculum, which is typical for strong state-centered government and the era's ideal of politically anchoring reform (Englund, 2012).

The exchange with other countries also made influential actors suggest a Swedish school computer infrastructure, something frequently echoed in the interviews. One pioneer referred to how comparisons pushed the idea forward: "Denmark had Pickoline, Finland Mikro-Mikro, and England the BBC computer. Norway had joined the Swedish project" (Nydahl, 2008). During the mid-1980s, the Swedish government and municipalities co- 
financed secondary school computer infrastructure (SEK 60 million 1984-1987) in parallel with the prolonged implementation of the new subject. The development of relevant software for the assigned computers brought problems, however. In the mid-1980s, the Swedish Ministry of Education (MoE) initiated a school software project and a Nordic expert group to exchange software. Although severe usability and interoperability problems occurred (characteristic for micro-computers then), these Nordic-produced state-financed programs later "turned into popular market products." Because "all these software programs were freely accessible as the organization ended" (Nydahl, 2008), the commercial sector could make a profit from them. One of the interviewees stated that the software projects were also outmaneuvered by new types of operating systems, Microsoft Office packages, and new focus on information search and process writing in schools. Two different interviews included similar retrospective comments:

We probably had our doubts that it was a dead-end project from the beginning, to make a Swedish blue-and-yellow computer. (Nilsson, 2008)

A Swedish school computer named Compis [Computer in School, procured in 1982], which one now, a few years after and with the facts at hand, regards as one of the biggest flops in Swedish technology development history. That computer was completely impossible to use. (Boström, 2008)

Hence, a Swedish-profiled school computer brand, similar to other countries, and schools and students having an automated teaching machine were considered ideal by government and industry at the time, and while the output can be considered limited in retrospect, the materialization of this strong imaginary was pervasive. The National Agency of Education (NAE, the public agency after NBE) called the 1980 s investments "almost textbook examples of technological push; computers were pushed onto schools and teachers that never asked for it" (NEA, 1999, p. 24). Taken together, state-initiated reforms and industry-oriented curriculum characterize this first digitalization reform period. This includes extensive power struggles over knowledge content on computerization and programming, where materialization of school computers gained important impact through the imaginary of Swedish society.

\section{ICTs, networks, and IT-billions in the 1990s decentralized curriculum}

The 1990s, particularly 1994, comprised several major reforms in Swedish politics and curricula. The period before had been characterized by power struggles over interests and investments, but is often described as a time of undecided matters for school digitalization (Jedeskog, 1996). A major education and public sector reform had begun in the 1980s, the decentralization and deregulation reform (Englund, 2012, 2018). With it, the responsibility for schools was regionally transferred to municipalities, including allocation of funds, 
which affected the school digitalization issues in the mid-1990s and onward. The overall curriculum was reduced to goal-oriented strategies to be operationalized by local schools and teachers. Local schools were also to provide for strategies and infrastructure, which according to one pioneer, made regional technological capacity better but more unevenly distributed. In 1994, when the second major reform of digitalization took off, due to decentralization, the municipalities were entrusted with responsibility for implementation, while the state-controlled NEA was responsible for coordination.

The new terminology was information technologies (IT). The curriculum prescribed students' ability to use IT as a "tool for knowledge seeking and learning" (MoE, 1994). According to the new primary school curriculum, Lpo94 (MoE, 1994), in line with imagined future needs, students should be "able to orient themselves in a complex reality, with a large flow of information and a rapid rate of change." These represent a will to reform connected to the back to the future argument. Education was to foster an IT-savvy citizen who contributed to the skills and knowledge of the information society, and IT was also used to substantiate such competence. The difference this time was the technologysaturated future economy imagined.

In 1994, the white paper "Wings for Human Ability" (IT Commission, 1994) epitomized the far-flung technology-positive ideas from the mid-199os. Persuasive visions of school use of IT or ICT added to these ideas. The internet and web had been introduced, and the information superhighway was a common socio-technical imaginary at the time. Arguments around global connectedness and investments in lifelong learning through individuals' digital skills became linked to economic competitiveness agendas (MoE, 2001), echoing the trans- and supra-national 21st century skills curriculum discourse in the United States, the Organization for Economic Co-Operation and Development (OECD), European Commission, and more. A new economic sector and strong national confidence had emerged with IT businesses establishing in Sweden, in a short-lived IT boom, and IT in schools gained new momentum (Karlsohn, 2009). For IT and education businesses, schools were increasingly seen as market investments, or "a gateway for future sales to companies," as one interviewee put it (Boström, 2008), in the belief that "students would prefer the computers they had used before" when they entered work life. Hence, the sociotechnical imaginary here draws on new forms of incentives for the desired future and schools as marketplaces. As part of this, networking became a renewed political tactic, and the public sector formed networks with private IT and education businesses. The NEA was commissioned to coordinate information networks, such as the national School Data Network, the resource-sharing platform Multimedia Department, and the Nordic Odin network. Networking also became part of the new curriculum by communicating the need to network humans and digital resources to support teaching and school development.

Social and digital networks also characterized how major investment was motivated in the 1990s. Important financial initiatives and efforts to digitize schools came from the 
Knowledge and Skills Development Foundation, The KK Foundation (SEK 1 billion), based on employee funds set up by the former left-wing government, now liquidated by the rightwing government. During a political hearing (IT Commission, 1998) comments were made about investments of the Lighthouse Project, set up to be a role model in 1995:

The one billion already is a lot of money, add to this the extraordinarily large sums that Swedish municipalities also spend, estimated to be another three billion from 1996 to the turn of the millennium (IT Commission, 1998, p. 21)

Added to these billions, teacher professionals who had made extra contributions to school development and renewal were issued an extra SEK 6 billion during the contract period, debatably referred to as forced reform adaptation for teachers. Other tensions included only 28 municipalities (out of over 280 then) having access to KK Foundation funding; the remainder had to make their own investments. As many municipalities refrained from investing in digitalization, the dissemination of results and experiences became more difficult, and the opportunities to reform were unevenly distributed economically and nationally.

A follow-up to the KK initiative was another large initiative (SEK 1.7 billion), "Tools for Learning, National Program for IT in Schools (ITIS)" (MoE, 1998). The idea was to improve schools' internet access, support teacher work teams with learning resources, and school development, also by appointing teacher education institutions. Students' learning was highlighted and set against traditional teaching, and the schools and teachers were guided to redefine their work on such grounds. All municipalities participated, but the investment did not take place generally and flexibly, meaning large investments in teacher PCs (SEK 700 million) was unevenly distributed. Even if funding provided a basic digital infrastructure in more schools, it also forced many municipalities into infrastructure agreements where technology providers got major influence over political decisions (National Audit Office, 2002). Similar to earlier initiatives, ITIS was criticized for neglecting earlier reforms and results and for being too quickly and sub-standardly prepared relative to the decentralized municipalities. It even started before the earlier KK Foundation project was ended and evaluated. One interviewee argued that the era's political initiatives had continual "government problems, [as] project after project followed but without interconnection" and said, "It would have been better if the state and municipalities had had a better collaboration," as "these changes are not made quickly" (Nydahl, 2008). Often depicted is the lack of national coordination but also the wait for local power distribution, given that decentralized municipalities were expected to strategically expand ICT into schools through their own large economic investments. One major municipality initiative became the local uptake of the global one-laptop-per-child movement in the early 200os, connecting municipal schools with major technology providers like Apple. The purchases were supported by regional stakeholders (e.g., The Swedish Association of Local Authorities and Regions, 2019) and philanthropic non- 
governmental organizations, often processed by private broker companies, made possible via public procurement. Education and IT businesses now got new opportunities to sell hardware, software, and training directly to schools. In a sense, the curriculum was thereby changed as how and why digitalization was introduced in schools was substantiated by private interests (c.f. Picciano \& Spring, 2013; Williamson et al., 2019).

Compared to the early 1960 s and 1970 s curricula, the ambition in the 1990 (and continuing in the 2010s) was greater and centered around accelerating Sweden's economic position in a global knowledge society and returning to the demand for current and future competitive citizen knowledge. The earliest reforms were more cautious and explored whether digital technology, mainly computers and computerization, came with issues that should be regarded in the curriculum. A more self-assured and internationally extended curriculum was established with the 1990s' alternative societal imaginary, which came to symbolize a society and citizen ideal with strong technology-deterministic faith (Jasanoff, 2015), confidently relying on individuals' abilities to process and exchange information. IT, or ICT, in combination with decentralized municipal education governance, shaped the subsequent curriculum, which also created further differentiation in terms of individualization and the distribution of infrastructure and education resources. A growing dependence on private-sector initiatives was also established, which resurfaced in the 2010s' major school digitalization reform, presented next.

\section{Adequate competences, coding and platforms in monopolized centralist reform}

During the 2010s, the term "digitalization" gained wide curricular impact, often described as more than digitizing information and, again, with a new terminology of ideals of an emerging digital future, a socio-technical imaginary, used to regulate the current curriculum. In the Swedish upper secondary school syllabus, Gy11 (NAE, 2011), digitalization is described in terms of students being able to "orient and to act in a complex reality with a large flow of information, increased digitalization, and rapid pace of change," and that students should "develop a critical and responsible approach to digital technology, to be able to see opportunities and understand risks and to value information." The more critical approach to information, in comparison to 1990 s curricula, was developed then, but mainly, the citizenship expressed is the individuals' adaptability to an already present and changeable future society different from the 1960 s ideal of a more stable, industrially prosperous society constituted by computers and scientifically informed knowledge.

Major digitalization reform came in 2017, represented by the national strategy (MoE, 2017), the overall aim of which was to increase equivalent (not equal) technological accessibility nationally. Modernization and a fundamental change of work methods, 
teaching, and leadership, as well as improved school cost effectiveness, were expressed. It is also said that with overall digitalization reform, "Sweden continually should be a leader in digitalization and be digitally competent" (MoE, 2017, p. 3-4). As shown here, digital competence could be used to address students and the nation-state, framed as actionable elements that form part of a global society and economy imaginary. The new agency, School Inspection, controlling juridical matters and quality (Englund, 2018), suggested teachers have an "open approach to new technology, rather than any specific technical competences" and that the desired effects of school digitalization included providing "increased student motivation, skills, and independency and support group work" (School Inspection, 2011, p. 8-9). A strong governance feature of the school digitalization curriculum was how it addressed behavioral attitudes, for both students and teachers, as part of being competent. As the NEA (2019) introduced the revised syllabi for digitalization, it was clear that the term "digital competence" was borrowed from influential actors like the OECD (2005), which had promoted an economy-based understanding of how global workforces and digital markets secure digitally competent citizens and students. A particular attribution to digital competence was introduced in the Swedish curriculum (MoE, 2017), stating it should be "adequate," a term for pointing out context adaptability and knowledge relevance. In line with Wahlström and Sundberg (2017), this suggests that the widespread competence concept from the mid-20oos was multidirectional and "domesticated" as it was transformed over time into particular situations, along with the Swedish context, and in line with globalized discourses.

Programming was formally reintroduced in the digitalization curriculum (MoE, 2017), based on several new knowledge formulations, integrated in all school years and different subject areas, similar to the late 1960 s and 1970 s reforms. Similar to earlier initiatives, programming knowledge and learning to code were referred to as desirable but now, however, fully oriented toward individuals' knowledge needs and future careers, as stated by a representative of NAE in 2018:

Everyone needs basic knowledge in programming to be able to understand how society functions and to then being able to use it in one's work life. That is why schools need to take this content into consideration so that every student will be taught this. There is an idea of progress in the programming curriculum from preschool class to upper secondary school, starting with the concrete step-wise instruction to being able to apply this programming for problem-solving in upper secondary school. (NAE, 2018-01-09)

Socio-technical imaginaries are part of how programming is positioned in society, framed as work knowledge and categorized into curricular knowledge of school levels and content areas. Even so, it is posted on NAE:s own YouTube channel as a sign of how a public agency today pictured the imagined world. Somewhat similar to the 1970s' curricular ideas of digital technology, programming knowledge is seen as an important aspect of a future 
emerging society. The late 2010 s ambition is, however, wider than the 1970 version and suggests more experimental initiatives; programming is now framed through aspects like contribution to a digitally-based economy.

In many ways, programming and learning to code as digital competences draw on the language of computer science and the conception of programming as a problem-solving skill. A possible reason for this is how the curriculum process was politically governed. NAE was appointed to operationalize the curriculum and distribute an important part of the project, Triple Helix-National Coalition for School Digitalization. This was initiated by Swedsoft (2017), a large software interest organization of academics and industry people, where schools, industry, and universities were invited to participate in different workshops. This exemplifies a new form of education reform where public and private actors, based on different interests and during short and fragmented time contributions, had a large impact on major curricular decisions and technology-use, similar to other countries (Williamson et al., 2019). In Sweden, these processes replaced earlier, more publicly visible curriculum-making, which were slow processes, as exemplified in the late 1960 s reform. The 2010s' state-led government decreased and transferred control to audits and inspections. These changes in Sweden and elsewhere exemplify a form of recentralization (Englund, 2012) of the curriculum in the 2010s. However, this recentralization is now supported via supra- and transnational organizations such as the OECD and other interest groups (Wahlström \& Sundberg, 2017) rather than being limited to the nation-state and public government. In that sense, there are impacts and similarities in the curricular focus as well as differences between the forms of centralism that took place in the 1960s and 2010s reforms to follow Englund (2012). This transformation makes the possibilities of democratic influence and criticism of rapidly upcoming political proposals more difficult.

The competence feature of the curriculum was paired with certain understandings of technology. Since the 1990s, Swedish school curriculum has commonly described digital technologies as tools for learning and work processes, a means of achieving other goals. The School Regulation (MoE, 2010), for example, suggested "that schools apart from books, also should use other learning tools needed for an up-to-date education." Similar expressions were used in 2017's national digitalization strategy, but now teachers' digital competence and their ability to choose and use digital tools (also referenced by the Teacher Union chair in the introductory quote) was more in focus. The tool metaphor used here to describe a preferred technology-based curricular repertoire that teachers should be able to choose from risks neutralizing the difference of digital technologies, software, hardware, and so on and how they are always inscribed and circumstanced with powers that make it hard to criticize or act upon the curricular repertoire. Even so, it presupposes a choice, preferably based on pedagogical (not solely economic) considerations. This stands in contrast to the establishment of a highly influential infrastructure, with learning platforms or learning management systems as a dominating technology (NAE, 2016). At first, these 
platform infrastructures had served more local settings and internal school networks, but now they evolved as ideas of standardizing administrative and pedagogical processes in schools, and they were built into the platform used in school systems.

Now a new form of global platform infrastructure, digital systems of hardware, software, and administration services in one package, has entered the growing competitive school market, mainly provided by major internet providers like Google or Microsoft. Major marketization reforms had opened the public education sector for commercial interests, including an independent profit-making school sector (Englund, 2018). The commercial logic of platform capitalism is that the "currency" and volume of data (Srnicek, 2017) generated by everyday school use of digital platform technologies and the infrastructures already in place make the price of the infrastructure affordable or "free" for schools in a costly public education sector (Williamson, 2017). Often, these private interests argue a philanthropic perspective that they contribute to the public good by, for example, monitoring data activity and student learning. In that sense, they impact considerably in imagining a digitalized education system as part of a society with a well-performing and well-managed digital economy. In Sweden, the media debate around this has concerned teacher workload costs and efforts and the disciplining assessment culture as the backside of standardized platform use (Swedish Teacher Union, 2019). More seldom questioned is how this "infrastructuralization" and data currency growing out of platform markets is changing power relations. The global platforms and school data practices instantiated and operating via private-public networks could now extract, assess, and compare local, national, or international performances (Hillman, Bergviken Rensfeldt \& Ivarsson, 2020), working as part of a new global monopolization and centralized power (Englund, 2018).

\section{Conclusion}

Two main results appear from our analysis of similarities and differences in major Swedish school digitalization curriculum reforms over the past 50 years.

One recurrent configuration is the back to the future argument, where curricula address ideal citizenships of emerging future societies and by such argumentative power give fuel to reform-starting with the industrial and welfare prosperity of the 1960s, to a break in 1990 and 2010s societies with internationally oriented information and latest knowledge economy versions. The discursive figure is strongly intertwined with inscriptions of and investments in digital technologies through school computers, digital information networks, and learning platforms, often co-constituted by international digitalization discourses and networks. Such socio-technical imaginaries "naturalize ways of thinking about possible worlds" (Jasanoff, 2015, p. 24). The alternative and implicit imaginary produced is a value-laden counternarrative of a Sweden lagging behind others, having uninformed citizens, and poor societal and educational conditions and infrastructures for knowledge production and prosperity. Even if digitalization reforms are aligned with such 
political tensions, interruptions, and resistance, we argue that there are converging visions over the 50 year period of meeting democratic and economic challenges by digital means in education.

The other is that major divergences in digitalization curriculum formations are strongly related to governance transformations that had differentiating consequences for opportunity and equal accessibility around digitalization. These significant political and curricular transformations add to Englund's analyses $(2012,2018)$ of the democratic role and purpose of education curricula. The pendulum movement between centralized and decentralized powers inherent in digitalization politics have been evident, in the 1960s by strongly state-led government and nation-oriented curricula, then followed by more locally distributed municipal power centers and curricular reform, and again re-centralized via more monopolized powers via supra-state and private actors influencing the curricular reform. Hence, one general insight is that the digitalization curriculum, often internationally oriented toward the economic aspirations of nation-states, such as competitiveness and human capital, in recent times is more challenged by and exposed to private interests (Picciano \& Spring, 2013, p. 173). In the governance break around 1990, in particular, changes in political-administrative processes affected curricular processes, strongly consistent with (international or supra-based) contexts and a global market reform orientation and "generally favourable to decreasing the role of the state in direct provision of public services” (Verger et al., 2017, p. 328). Social networks and infrastructurally converging models, however, seem to have been internationally multidirectional since the early international exchanges around digitalization. As the 1990 break opens up for private and commercial interests, these also gain influence over school infrastructures. Together, state and privatized initiatives have, over time, created a strong infrastructure base for Swedish schools, a development not without complications, however. Inequality issues and related democratic challenges of school digitization have appeared.

Several of Englund's analyses (e.g., 2012, p. 21; 2018) exemplify how the Swedish curriculum orientation from 1960 to the mid-1980s was driven by strong education reforms aimed at counterbalancing student inequalities, followed by the radical break around mid-1980s (Englund, 2018), with free school choice, for-profit schools, and more. Even if equal access to technology has similarly been a constant struggle in digitalization reform since the early 1960s, beginning in the 2010s, a new take on equivalent technology access has been used in strategies (e.g. MoE, 2017), allowing for differences and unresolved problems of interoperability, standardization, and accessibility of digital technologies. The main guarantees provided are market offers of digital competence resources and public procurement of global platform infrastructures where digitalization is considered a powerful instrument for improving, democratizing, and making different aspects of schooling more efficient and streamlined. Implicit in socio-technical imaginary is how the opportunity and capacity of technology for learning and competence 
development is addressed toward students, schools, nations, and the future at the same time as the technologies are inscribed with certain uses and standards that counteract such concerns.

In the actual implementation of school digitalization over time, the detailed regulation of instituting reform seems to decrease, while performativity and assessment regimes increase, especially the 2010s' reform, which allows for different types of data introspection and exploitation from private and commercial interests. This includes the insertion of commercially provided platform technologies into public education, who can now profit from school-generated data activities and get direct access to public education sector performativity in different ways. Similarly, the latest decade's fast and decentralized curricular transformations differ from the earlier, more slow-paced education reforms, where curricula and investments in, for example, school computers were commonly publicly discussed via official organizations of unions and employers. This shift in power struggles over curricula makes it important to include new, more ephemeral empirical material from private sector actors and 'actants' like infrastructures and platforms. The education system and the schools may need to develop knowledge on these new forms of curricular changes and an approach to safeguard the interests of the public education sector and the values at stake, such as issues of equality, openness, personal integrity, and the utilization of schools' digital work on platforms (Williamson, 2017; Hillman et al., 2020).

\section{References}

Ball, S., \& Youdell, D. (2008). Hidden privatisation in public education. Education International. https://issuu.com/educationinternational/docs/hidden-privatisation

Hillman, T. Bergviken Rensfeldt, A., \& Ivarsson, J. (2020). Brave new platforms: A possible platform future for highly decentralized schooling. Learning, media and Technology, 45(1). https://doi.org/10.1080/17439884.2020.1683748

Bernstein, B. (2000). Official knowledge and pedagogic identities: The Politics of Recontextualisation. In B. Bernstein, Pedagogy, symbolic control and identity: Theory, research, critique. (pp. 65-79). Rowman \& Littlefield.

Boström, J. (2008). Interview from 2008 by Martin Emanuel. Division of history of science and technology. Royal Institute of Technology. https://tekniskamuseet.se/wp-content/uploads/2017/o8/134-jan-bostrom.pdf

Broman, Ö., \& Bäck, M. (2008). Interview from 2008 by Martin Emanuel. Division of history of science and technology. Royal Institute of Technology.

https://tekniskamuseet.se/wp-content/uploads/2017/08/130-orjan-broman-ochmats-back.pdf 
Emanuel, M. (2009). Datorn i grundskolan, gymnasieskolan och i folkbildningen. Slutrapport. Project Från matematikmaskin till IT. [Project Computers in Primary and Upper Secondary School and Popular Education]. Royal Institute of Technology. https://www.tekniskamuseet.se/samlingar/forskning/fran-matematikmaskin-till-it/

Englund, T. (2012). Utbildningspolitisk monopolism - nya utmaningar för läroplansteori. [Monopolism in education politics: new challenges for curriculum theory]. In $\mathrm{T}$. Englund, E. Forsberg, E. \& D. Sundberg (Eds.), Vad räknas som kunskap? Läroplansteoretiska utsikter och inblickar i lärarutbildning och skola. (pp. 20-38). Liber.

Englund, T. (2018). Två artskilda perioder för pedagogisk forskning. [Two distinct periods of educational research]. Pedagogisk forskning i Sverige, 23(5), 1-23. https://doi.org/10.15626/pfs23.5.02

Grek, S., Maroy, C., \& Verger, A. (Eds.) (forthcoming). Accountability and datafication in the governance of education. World Yearbook of Education 2021. Routledge.

Gulson, K.N. \& Sellar, S. (2019). Emerging data infrastructures and the new topologies of education policy. Environment and Planning D: Society and Space, 37(2). https://doi.org/10.1177/0263775818813144

Hallsén, S., \& Nordin, A. (2020). Variations on moodernisation: Technological development and internationalisation in local Swedish school policy from 1950 to 2000, Scandinavian Journal of Educational Research, 64(2), 151-166. https://doi.org/10.1080/00313831.2018.1524396

Hanell, F. (2018). What is the 'problem' that digital competence in Swedish teacher education is meant to solve? Nordic Journal of digital literacy, 13(3), 137-151. https://doi.org/10.18261/issn.1891-943x-2018-03-02

Haugsbakk, G. (2013). From Sputnik to PISA shock: New technology and educational reform in Norway and Sweden. Education Inquiry, (4)4. https://doi.org/10.3402/edui.v4i4.23222

IT Commission (1994). Vingar åt människans förmåga: IT. [Wings for Human Ability: IT.] SOU 1994:118. Informationsteknologikommissionen.

IT Commission (1998). Schools, IT and the lifelong learning. SOU 1998:70. Informationsteknologikommissionen.

Jasanoff, S. (2015). Future imperfect: Science, technology, and the imaginations of modernity. In S. Jasanoff \& S-H. Kim, (Eds.). Dreamscapes of modernity: Sociotechnical imaginaries and the fabrication of power (pp. 1-33). The University of Chicago Press. https://doi.org/10.7208/chicago/9780226276663.001.0001 
Jedeskog, G. (1996). Lärare vid datorn: Sju högstadielärares undervisning med datorer 1984-1994. [Teachers at the computer: Seven primary school teachers' computer teaching]. Linköping University.

Jedeskog, G. (2005). Ch@nging school: Implementation of ICT in Swedish school, Campaigns and Experiences 1984-2004. Uppsala University.

Karlsohn, T. (2009). Teknik-Retorik-Kritik: Om IT-bubblan och datoriseringen av den svenska skolan. [Technology-Rhetoric-Critique: On the IT boom and computerization of the Swedish school]. Carlsson.

Lundgren, U.P. (2015). When Curriculum Theory came to Sweden. Nordic Journal Of Studies In Educational Policy, 2015(1), 5-13.

https://doi.org/10.3402/nstep.v1.27000

McBride, K. (2019). Sailing towards digitalization when it doesn't make cents? Analysing the Faroe Islands' new digital governance trajectory. Island Studies Journal, 14(2), 193-214. https://doi.org/10.24043/isj.93

McGarr, O., \& Johnston, K. (2019). Exploring the evolution of educational technology policy in Ireland: From catching-up to pedagogical maturity. Educational Policy. https://doi.org/10.1177/0895904819843597

Ministry of Education (1994). Läroplan för det obligatoriska skolväsendet och de frivilliga skolformerna: Lpo94 och Lpf94. [Curriculum for the compulsory school, the pre-school class and the after school centre]. Utbildningsdepartementet.

Ministry of Education (2001). Debatten om det livslånga lärandet. Den nationella konsultationen om EU-kommissionens memorandum om livslångt lärande 2001. [Debate on lifelong learning: National consultation on the European Comission's memorandum on lifelong learning 2001]. Utbildningsdepartementet.

Ministry of Education (2010). Skollag SFS 2010:80o. [School law 2010:800]. Utbildningsdepartementet.

Ministry of Education (2017). Nationell digitaliseringsstrategi för skolväsendet. [National digitalization strategy for the school system]. Utbildningsdepartementet.

Ministry of Education and Science (1998). Tools for learning: A national programme for ICT in schools. ITIS, Delegation for ICT in schools.

National Agency of Education (1999). ”...utvecklingen beror då inte på användningen av datorer." ["...at least the development is not related to computer-use"]. Skolverket.

National Agency of Education (2016). IT-användning och IT-kompetens. [IT use and IT competence]. Skolverket.

National Agency of Education (2011). Läroplan (Gy11) för gymnasieskolan. [Curriculum for the upper secondary school]. Skolverket. 
National Agency of Education (2018-01-09). Programmering i läroplanen. [Programming in the curriculum]. [Video]. YouTube. https://voutu.be/YS6OAfbqBxg.

National Audit Office (2002). Riksdagens revisorers förslag angående ITiS - en statlig satsning på IT i skolan. [Revision on ITiS: a government investment in schools]. 2001/o2 RR2O. Riksrevisionen.

National Board of Education (1980a). Läroplan för skolan: Lgr8o. [School curriculum: Lgr8o]. Skolöverstyrelsen.

National Board of Education (1980b). Datorn i skolan. SÖ:s handlingsprogram och slutrapport. [The computer in school: Action programme and report from NBE]. Skolöverstyrelsen.

Nilsson, B. (2008). Interview from 2008 by Martin Emanuel. Division of history of science and technology. Royal Institute of Technology.

https://tekniskamuseet.se/wp-content/uploads/2017/08/135-bengt-nilsson.pdf

Nilsson, R., \& Loftrup, B. (2008). Interview from 2008 by Martin Emanuel. Division of history of science and technology. Royal Institute of Technology..

https://tekniskamuseet.se/wp-content/uploads/2017/o8/104-rolf-nilsson-och-boloftrup.pdf

Nivala, M. (2009). Simple answers for complex problems: Education and ICT in Finnish information society strategies. Media, Culture \& Society, 31(3), 433-448. https://doi.org/10.1177/0163443709102715

Nydahl, G. (2008). Interview from 2008 by Martin Emanuel. Division of history of science and technology. Royal Institute of Technology.

https://tekniskamuseet.se/wp-content/uploads/2017/08/129-goran-nvdahl.pdf

OECD (2005). The OECD Program Definition and Selection of Competencies. OECD.

Picciano, A.G., \& Spring, J.H. (2013). The great American education-industrial complex: Ideology, technology, and profit. Routledge.

https://doi.org/10.4324/9780203120613

Popkewitz, T.S. (2008). Cosmopolitanism and the age of school reform: Science, education and making society by making the child. Routledge.

Riis, U. (1987). Datalära på grundskolans högstadium - Utvärdering av en treårssatsning. [Computer science education in the Swedish lower secondary school: Evaluation of a three years' campaign]. Linköping University.

Riis, U. (2008). Interview from 2008 by Martin Emanuel. Division of history of science and technology. Royal Institute of Technology. https://tekniskamuseet.se/wpcontent/uploads/2017/08/136-ulla-riis.pdf 
Saari, A., \& Säntti, J. (2019). The rhetoric of the 'digital leap' in Finnish educational policy documents. European Educational Research Journal, 17(3), 442-457. https://doi.org/10.1177/1474904117721373

School Inspection (2011). Litteraturöversikt för IT-användning i undervisningen. [Literature review for IT-use in teaching]. Skolinspektionen.

Selwyn, N. (2002). Learning to love the Micro: The discursive construction of 'educational' computing in the UK, 1979-89, British Journal of Sociology of Education, 23(3), 427443. https://doi.org/10.1080/0142569022000015454

Selwyn, N. (2013). Researching the once-powerful in education: the value of retrospective elite interviewing in education policy research. Journal of Education Policy, 28(3), 339-352. https://doi.org/10.1080/02680939.2012.728630

Srnicek, N. (2016). Platform capitalism. Polity Press.

Swedish Association of Local Authories and Regions (2019). \#skolDigiplan. Nationell handlingsplan för digitalisering av skolväsendet. [SchoolDigiplan. National action program for the digitalization of schools]. Sveriges kommuner och landsting.

Swedsoft (2017). Trippel Helix: Nationell samling för skolans digitalisering. [Triple Helix: National collaboration on school digitalization]. https://www.swedsoft.se/

Tafdrup. O. (2019). Sociotechnical imaginaries in the digital age of education. Aarhus University Diss.

https://pure.au.dk/portal/files/145560253/Afhandling OliverTafdrup.pdf

Teacher Union magazine (2017-10-20). Den nya digitaliseringsstragin. [The new digitalization strategy]. Lärarnas tidning.

Teacher Union (2019). Stör- eller stödfunktion: En rapport om lärplattformar. [Interference or support: Report on learning platforms]. Lärarförbundet.

Verger, A., Steiner-Khamsi, G. \& Lubienski, C. (2017). The emerging global education industry: Analysing market-making in education through market sociology. Globalisation, Societies and Education, 15(3), 325-340. https://doi.org/10.1080/14767724.2017.1330141

Wahlström, N., \& Sundberg, D. (2017). Discursive institutionalism: Towards a framework for analysing the relation between policy and curriculum. Journal of Education Policy, 33(1), 163-183. https://doi.org/10.1080/02680939.2017.1344879

Williamson, B. (2017). Big data in education: The digital future of learning, policy and practice. Sage. https://doi.org/10.4135/9781529714920

Williamson, B., Bergviken Rensfeldt, A., Player-Koro, C., \& Selwyn, N. (2019). Education Recoded: Policy Mobilities in the International 'Learning to Code' Agenda. Journal of Education Policy, 34(5), 705-725. https://doi.org/10.1080/02680939.2018.1476735 